\title{
BEYOND ECONOMIC GROWTH: SUSTAINABLE DEVELOMENT AS AN ALTERNATIVE APPROACH
}

\section{Além do crescimento econômico: desenvolvimento como uma abordagem alternativa}

sustentável

Thauan Santos ${ }^{1}$

\section{Introduction}

At all times we hear on the news and read in the headlines that the economy of a particular country grew or declined. The metric is very simple: growing is a proxy for a "good job", yet declining for a "bad job". The most used measure for such analysis is the well-known gross domestic product (GDP), which can be understood as the total market value of all final goods and services produced within a country during a given period.

This measure was developed during the 1930's and 1940's, after the Great Depression and the World Wars. In the post-World War II, some events took place, such as the signing of the Bretton Woods agreements, the initial discussions that would lead to the uprising of the United Nations (UN) and to the bipolar environment of the Cold War. Needless to say, the competition between the two sides of the bipolar war was expressed in measurable outcomes, and the GDP measure became the main objective pursued by countries and it undoubtedly grew into the flagship among these competing models.

The point is that this international structure guided by economic growth is the result of structural models of international economic and financial relations (EICHENGREEN, 2018; GILPIN, 2016). These outcomes and measures continue to be references for trade flows and international investments as well as to the credibility (or not) of the economies. Obviously, its relevance ends up becoming a "self-fulfilling prophecy”, that makes people and different countries not even question these data, but seek them above everything - resulting in the maintenance of the international productive and financial system status quo (YOSHINO et al., 2018).

The use of GDP as a metric to evaluate development is already outdated and old fashioned, since it only considers economic growth without taking into account the negative externalities of production on the environment and the scarcity of natural resources. In this way, the following section will present in more

\footnotetext{
${ }^{1}$ Thauan Santos é professor adjunto da Escola de Guerra Naval (EGN) e pesquisador do Conselho Latino-Americano de Ciências Sociais (CLACSO). Foi professor da UFRJ, UERJ e PUC-Rio. Email: santos.thauan@gmail.com
} 
detail the reasons why it is necessary to overcome this metric, even though it continues to be used to rank countries in the most different studies and international analysis.

\section{Leaving GDP behind}

It is well-known that GDP includes consumption, government spending, investment and net exports (FRANKEL, 2016; JONES, 2015). It does not take into account some of the negative effects of economic growth, like pollution, neither considers leisure time, nor parts of the informal economy (RAMPELL, 2008). Therefore, GDP measures mainly market transactions, ignoring social costs, income inequality and environmental impacts (SANTOS, 2018). As Robert F. Kennedy (1968) once said, "the gross national product does not allow for the health of our children, the quality of their education, or the joy of their play. (...) it measures everything, in short, except that which makes life worthwhile.” The idea behind this indicator is the more we produce the better. In other words, it is an only and exclusively quantitative analysis (IVKOVIĆ, 2016; THE ECONOMIST, 2016).

Economic growth does not critically evaluate its relationship with the availability of natural resources, especially when dealing with non-renewable resources. Then, GDP is dangerously inadequate as a measure of quality of life, what was also echoed in "The Future We Want", the declaration of the Rio+20 UN Conference on Sustainable Development agreed upon by all UN member states, and the Paris Agreement. Nonetheless, GDP remains entrenched and indeed relevant (COSTANZA et al, 2014).

For politicians and most economists, growth is necessary to job creation and the health of businesses. Common sense would conclude that without the highly desirable economic growth, it would be required from the government greater responsibilities, leading to the fall of tax revenues and increasing the public deficit. However, defining a healthy economic environment is not limited to evaluating the economic indicators strict sense, because as far as we know, economics is an applied social science and, in this sense, deals with human beings (HOWARTH; KENNEDY, 2016; COSTANZA et al., 2009; STEVENSON; WOLFERS, 2008).

It is also known that the (micro)economics mainstream treats individuals as homo economicus, who seek to maximize their satisfaction, considering their monetary restrictions (ATTICK, 2017; BRZEZICKA; WISNIEWSKI, 2014; THALER, 2000). However, Robert Gilpin (1999), Herbert Simon (1955) and Bryan Jones (1999) have already pointed out the limitations of such rational approach and of the disassociation between economics and politics.

The search for the maximization of production and often profits leads to the overexploitation of certain natural resources, ignoring the intertemporal perspective of the exploitation of factor endowments. Consequently, the debate arises about royalties and other incomes that aim to deal with the exploitation of these (nonrenewable) natural resources, but does not necessarily consider the diversity of factors and variables existent. Therefore, there is the need to consider social, environmental and political variables on these analyses. 
The oil crises of the 1970's showed how key inputs of production processes could reduce economic growth on a global scale. In addition, today we have the unquestionable role of international financial markets, which makes speculation, expectations and volatility of economic data increase even further, leading to the famous (cyclical) international crisis, as illustrated most recently by the subprime mortgage crisis in 2007 (from 2008 onwards, it became a global financial crisis) and the Eurozone crisis. Therefore, it is important to question how far policymakers will understand the cyclical and interrelated nature of these crises, rooted in often neglected data and statistics, or insist that each of these crises are just another turning of the business cycle. In this sense, it is important to note the unstable feature of these metrics and dynamics, and finally to envisage alternatives to them.

\section{Alternatives to economic growth}

Alternative measures to economics growth can be separated into three main groups (COSTANZA et al., 2014). Those in the first one adjust economic measures to reflect social and environmental factors. The second group consists of subjective measures of well-being drawn from surveys. The last one relies on weighted composite indicators of well-being including housing, life expectancy, leisure time and democratic engagement.

In the first group, and still according to the authors, we could mention the Genuine Progress Indicator (GPI), which is calculated by starting with personal consumption expenditures, and making more than twenty additions and subtractions to account for factors such as the value of volunteer work and the costs of crime and pollution. Another example is the Green Growth that according to the Organization for Economic Co-operation and Development (OECD, 2017) provides a practical and flexible approach for achieving concrete and measurable progress across its economic and environmental pillars, while taking full account of the social consequences of greening the growth dynamic of economies.

In the second group, we could mention the World Values Survey (WVS), which covers about seventy countries and includes questions about how satisfied people are with their lives. Another example is the Gross National Happiness (GNH) adopted in Bhutan that uses elaborate surveys on how content people feel in nine domains of their lives.

Finally, in the third group it is believed that to better understand the sustainable societal wellbeing, we have to consider both subjective and objective indicators. Examples are the Happy Planet Index (HPI). Another index also developed by the OECD (2011), and the Better Life Index (BLI) that maintains a website allowing users to choose among a class of different weights for their variables, revealing how the emphasis on different variables/weights can influence countries' rankings.

Although they are divided into three different groups, there is a common ground among them, namely the concept of limits. Such concept of limits is an old theme, ranging from limits on arable land (MALTHUS, 1836), to energy and material limits (MEADOWS et al., 1972) and to the economic scale and thermodynamic limits of ecological economists (DALY, 1979). On the other hand, there are authors like 
Simon (1981) that are technological optimists and believe that technology performs a fundamental role in minimizing this issue.

Most recently, the Sustainable Development Goals (SDGs) were built in a worldwide negotiation process. They constitute an agenda adopted at the UN Sustainable Development Summit, in September 2015, consisting of 17 goals and 169 goals to be achieved by 2030. The SDGs came into force in January 2016. In this agenda, broad global actions are planned in areas such as poverty eradication; food safety; agriculture; health; education; gender equality; reduction of inequalities; energy; water and sanitation; climate change; sustainable cities; inclusive economic growth; infrastructure; and industrialization. Note that economic growth is not exclusive, nor the main driver of this agenda.

However, there are still limitations associated with the use of indicators used in the SDGs, but it is essential to consider them as a kind of thermometer capable of measuring the dynamics and evolution of these goals (SANTOS; SANTOS, 2017). However, great efforts have been made to consider a diversity of spectra and areas directly and indirectly related to sustainable development.

A danger related to these metrics is the following: the use of these indicators can take into account the particularities inherent to the regions of the globe or may suggest a unique and 'correct' conception of what is sustainable development? As highlighted, the selected indicators are global and, in this sense, are not able to capture local and regional particularities. In this way, there are some extra challenges and threats that must be considered, in addition to the indicators themselves.

\section{Threats to face}

First of all, it is necessary to point out that changing the structural design of economic growth for sustainable development will require strong political will. The development concept can be interpreted as an 'umbrella' concept that considers not only economic issues, but also social, political, cultural, gender and institutional ones, in addition to human rights.

In the eyes of some people, surely this (new) index definition can represent a tremendous boldness, but we have to consider that the definition of the concept of economic growth as the protagonist indicator already had to be arbitrated someday and therefore it is not an unquestionable and ahistorical variable. In this way, it is important to understand the historical roots of current debates about economic growth, questioning the very logic of growth as an absolute rule (CARADONNA, 2017; FIORAMONTI, 2017).

It was actually social constructed, from the idea that increased production and productivity would be synonymous with economic growth in 'the wealth of nation', as most evidently suggested since the eighteenth century (DALE, 2017; SMITH, 2013).

Thus, we realize that there will be significant resistance to this change, mainly due to political and economic lobbies that often have strong power and influence on decision making. As an example, it is worth noting that the former US President Bill Clinton's small move towards a “green GDP” was killed by the coal industry. In addition to the strong inflexibility of the political structure of the system, particularly due to 
industries and producers that benefit from the modus operandi, Costanza et al. (2014) argue that much of the problem is because there is no alternative measure standing out as a clear successor.

This becomes even more serious if we consider the rate of economic growth of the well-known "emerging countries", such as the BRICS. Conditionalities imposed by international financing and foreign investments are guided almost exclusively by these rates of economic growth, what encloses these countries with the status quo, limiting more-sustainable models of development. Thus, there is no consensus that the international financial structure promotes or drives economic growth (POPOV, 2017; BIRD, 2016). Again, it is clear the systemic and international nature of this dynamic.

Once the signs for this limited conception of economic growth have become evident, markets operate through advertisements and planned obsolescence, forcing individuals (interpreted exclusively as consumers) to integrate this machine, being key parts and tools to its operation. Notwithstanding, cultural values and norms also play an important role as they shape our decisions and behaviors (NIROUMAND, 2014).

Other threats must be taken into account. In 2015, the US was concerned about discussing the ways in which the total output of the economy could be better measured, by proposing the gross domestic output (GDO), a more accurate measure of current economic growth. In addition, in 2014 the EU work entitled "Evaluating Alternatives to GDP as Measures of Social Welfare/Progress" claims that there is no sign that the world is ready for replacing GDP. It concludes stating that "we should not wait to eliminate or substitute GDP by another measure until a perfect alternative welfare indicator is available" (VAN DEN BERGH; ANTAL, 2014). In other words, "let's continue using the GDP and the economic growth anyway".

\section{Conclusion}

Our relentless focus on GDP has become an unhealthy obsession and a perverting influence on human well-being and happiness - but only because we allow it. Thus, thinking about alternatives is not just something that is expected, but something has to be done with all caution and haste.

First, we do need to reshape our entire economic system. At least initially, we need to make effective and efficient initiatives that punish disrespect against the limits of nature through set up market signals to change corporate and consumer behavior. Secondly, we can think beyond the logic of markets, stressing the need to consider the literature on subjective well-being and happiness (KAHNEMAN et al., 2004).

With regard to indicators of economic growth, we need them to be more complex, bringing inward subjective and objective variables, quantitative and qualitative analysis, and general and particular sights. Yet surely the critics would emphasize the difficulty in comparing these indicators across countries, but the question that arises is whether these indexes are created to allow international comparisons or basically serve as a thermometer to assess the outcome of certain policies and consequently help defining new ones. 
Richard Heinberg (2011) argues that there is light at the end of the tunnel since we focus on improving quality of life rather than boosting quantity of consumption (HEINBERG, 2011). Here, it is worth considering Amartya Sen's Development as Freedom (1999), when he points out that freedom (political freedoms, economic facilities, social opportunities, transparency guarantees, and protective security) is both the primary end and the principal means of development. Yet citing the same author, Amartya Sen's (1989) classic "Poverty and Famines" shows that problems from economic growth are more related to inequality access than shortage of resources, so the best way to deal with development is through the capability approach, that is a broader and deeper alternative concept than narrowly economic metrics.

This structural change in the economy will certainly lead to an institutional change (ELSNER, 2014; OSTROM, 2005; NORTH, 1990), as with the end of the gold standard, with the aforementioned with Bretton Woods system. Consequently, it will lead to a behavioral transformation (KORNAI et al., 2008; HODGSON, 2004, 2007).

Thus, it is quite trivial to realize that there is no magic nor a single index to better replace the "economic growth" approach; in other words, it will depend on many circumstances, such as economic, political, historical and institutional ones - what we can ensure is that sustainable development, as a broad approach can better suit the issue. Having said that, each country should choose its priorities and goals and then select the best way to plan and to measure it.

\section{BIBLIOGRAPHY}

ATTICK, D. Homo Economicus at School: Neoliberal Education and Teacher as Economic Being. Educational Studies, vol. 53, 2017, p. 37-48.

BIRD, G. The Effect of IMF Programmes on Economic Growth in Low Income Countries: An Empirical Analysis. The Journal of Development Studies, v. 53, issue 12, 2017, p. 2179-2196.

BRZEZICKA, J.; WISNIEWSKI, R. Homo Oeconomicus and Behavioral Economics. Contemporary Economics, vol. 8, Issue 4, 2014, p. 353-364.

CARADONNA, J. L. An Incompatible couple: a critical history of economic growth and sustainable development. In: BOROWY, I.; SCHMELZER, M. (Eds.). History of the future of Economic Growth: Historical roots of current debates on sustainable degrowth. New York: Routledge, 2017, p. 154173.

COSTANZA, R. et al. Development: Time to leave GDP behind, Nature, 2014. Disponível em: www.nature.com/news/development-time-to-leave-gdp-behind-1.14499.

COSTANZA, R; HART, M.; POSNER, S; TALBERTH, J. Beyond GDP: The Need for New Measures of Progress. The Pardee Papers, No. 4. Boston: Pardee Center for the Study of the Longer-Range Future, 2009.

DALE, G. Seventeenth-century origins of the growth paradigm. In: BOROWY, I.; SCHMELZER, M. (Eds.). History of the future of Economic Growth: Historical roots of current debates on sustainable degrowth. New York: Routledge, 2017, p. 27-51.

DALY, H. E. Entropy, growth and political economy of scarcity. In: SMITH, V. K (Ed.). Scarcity and Growth Reconsidered. Baltimore: Johns Hopkins University Press, 1979, p. 67-94.

EICHENGREEN, B. Global Monetary Order. European Central Bank, 2016, p. 21-63. 
ELSNER, W. The Theory of Institutional Change Revisited: The Institutional Dichotomy, Its Dynamic, and Its Policy Implications in a More Formal Analysis. Journal of Economic Issues, v. 46, Issue 12, 2012, p. 1-44.

FIORAMONTI, L. Gross domestic problem: how the politics of GDP shaped society and the world. In: BOROWY, I.; SCHMELZER, M. (Eds.). History of the future of Economic Growth: Historical roots of current debates on sustainable degrowth. New York: Routledge, 2017, p. 91-109.

FRANKEL, J. Macroeconomic Review. Harvard Education, 2016.

GILPIN, R. International Political Economy, New York, Presage, 1999.

GILPIN, R. The Political Economy of International Relations. Princeton, New Jersey, 2016.

GROVER, S. 5 Economic Alternatives to the Cult of GDP. Three Hugger. Disponível em: www.treehugger.com/economics/5-philosophies-challenge-gdp-arbiter-human-well-being.html

HEINBERG, R. Life after the end of economic growth. The Guardian, 2011. Disponível em: http://www.theguardian.com/commentisfree/2011/nov/30/end-of-growth.

HODGSON, G. M. The Evolution of Institutional Economics: Agency, Structure and Darwinism in American Institutionalism. Routledge, 2004.

. The Revival of Veblenian Institutional Economics. Journal of Economic Issues, v. 16, n. 2, 2007, p. 325-340.

HOWARTH, R. B.; KENNEDY, K. Economic growth, inequality, and well-being. Ecological Economics, v. 121, Jan. 2016, p. 231-236.

KAHNEMAN, D. et al. Toward national well-being accounts. American Economic Review, Papers and Proceedings 94, 2004, p. 429-434.

IVKOVIĆ, A. F. Limitations of the GDP as a measure of progress and well-being. Ekonomski Vjesnik, XXIX, 1/2016, p.257-272.

JONES, C. I. The Facts of Economics Growth. NBER Working Paper Series, N. 21.142, 2016.

JONES, B. D. Bounded Rationality. Annu. Rev. Polit. Sci., 2, 1999, p. 297-321.

KORNAI, J.; MÁTYÁS, L.; ROLAND, G. (Eds.) Institutional Change and Economic Behaviour. International Economic Association Series, Palgrave Macmillan UK, 2008.

MALTHUS T. R. Principles of Political Economy. Cambridge: Cambridge University Press, [1836], 1989.

MEADOWS, D. H., MEADOWS, D. L., RANDERS, J., BEHRENS, W. W. The Limits to Growth. New York: Signet, 1972.

NIROUMAND, A. M. An alternative to Economic Growth. What's our new story?, 2014. www.amirniroumand.org/if-not-economic-growth-then-what/

NORTH, D. Institutions, Institutional Change and Economic Performance. Cambridge: Cambridge University Press, 1990.

OSTROM, E. Understanding Institutional Diversity. Princeton: Princeton University Press, 2005.

OECD. Green Growth Indicators 2017. Paris, France, 2017.

OECD. Better Life Index. Paris, France, 2011. Disponível em: http://stats.oecd.org/index.aspx?DataSetCode=BLI. 
POPOV, A. Evidence on finance and economic growth. Working Paper Series, European Central Bank (ECB), N. 2115 / December, 2017. Disponível em: https://www.ecb.europa.eu/pub/pdf/scpwps/ecb.wp2115.en.pdf?47e5f3013cc176b0bd7fb8d3131d4 bc9.

RAMPELL, C. Alternatives to GDP. Economix. 2008. Disponível em: www.economix.blogs.nytimes.com/2008/10/30/alternatives-to-the-gdp/? $\mathrm{r}=0$.

SANTOS, T. Regional Energy Security: Re-evaluating concepts and policies to promote energy integration in Mercosur. PhD Thesis, PPE/COPPE/UFRJ, 2018.

SANTOS, L.; SANTOS, T. Os ODS e seus indicadores: novas classes gramaticais, uma mesma morfologia. Pontes, v. 13, 2017, p. 13-17.

SEN, A. Development as Freedom. New York: Alfred A. Knopf, 1999.

Poverty and Famines: An Essay on Entitlement and Deprivation. New York: Oxford University Press, 1981.

. “Development as Capability Expansion”, Journal of Development Planning 19, 1989, p. 41-58.

SIMON, H. A. A Behavioral Model of Rational Choice. The Quarterly Journal of Economics, v. 69, n. 1, 1955, p. 99-118.

SIMON, J. L. The Ultimate Resource. Princeton (NJ): Princeton University Press, 1981.

SMITH, A. The Wealth of Nations. London: Methuen, 2013.

THALER, R. H. From homo economicus to homo sapiens. The Journal of Economic Perspectives, v. 14, n. 1, 2000, p. 133-141.

STEVENSON, B.; WOLFERS, J. Economic Growth and Subjective Well-Being: Reassessing the Easterlin Paradox. NBER Working Paper Series, 2008, p.1-79.

THE ECONOMIST. The trouble with GDP. Briefing The Economist, April 30 ${ }^{\text {th }}$ 2016. Disponível em: https://www.economist.com/news/briefing/21697845-gross-domestic-product-gdp-increasinglypoor-measure-prosperity-it-not-even.

VAN DEN BERGH, J., ANTAL, M. Evaluating Alternatives to GDP as Measures of Social Welfare/Progress, $2014 . \quad$ Disponível em: www.foreurope.eu/fileadmin/documents/pdf/Workingpapers/WWWforEurope_WPS_no056_MS211. pdf.YOSHINO, N.; RANA, P. B.; MORGAN, P. J. Global Shocks and the New Global and Regional Financial Architecture: Asian perspectives. Asian Development Bank Institute, 2018. 


\title{
RESUMO
}

Este artigo tem como objetivo fazer uma revisão crítica do conceito de crescimento econômico. Assim, uma breve apresentação de indicadores alternativos é feita. Portanto, alguns indicadores são apresentados, assim como suas limitações, e as principais ameaças a serem enfrentadas são destacadas. Consideram-se discussões recentes no âmbito do Acordo de Paris e da Agenda 2030, que basicamente visa cobrir mais variáveis e questões relacionadas ao desenvolvimento sustentável. Por fim, apresentamos algumas considerações finais sobre o tema, ressaltando a necessidade de mudar não apenas as ferramentas econômicas analíticas de crescimento e desenvolvimento, mas entendendo que o conceito de desenvolvimento sustentável requer mudanças de hábitos, instituições e métricas.

Palavras-chave: Desenvolvimento Sustentável, Crescimento Econômico, Indicadores.

\begin{abstract}
This paper aims to make a critical review of the concept of economic growth. Hence, a brief presentation of alternative indicators is made. Therefore, some indicators are presented, as well as their limitations, and then the main threats to be faced are highlighted. Recent discussions under the Paris Agreement and Agenda 2030 are considered, which basically aims to cover more variables and issue areas when it comes to sustainable development. Finally, we present some final considerations about the theme, stressing the need to change not only the economic analytical tools of growth and development, but understanding that the concept of sustainable development requires changes in habits, institutions and metrics.
\end{abstract}

Key-words: Sustainable Development, Economic Growth, Indicators. 